\title{
STUDI FENOMENOLOGI : STRATEGI PELAKSANAAN YANG EFEKTIF UNTUK MENGONTROL PERILAKU KEKERASAN MENURUT PASIEN DI RUANG RAWAT INAP LAKI LAKI
}

\author{
Sujarwo ${ }^{1}$, Livana $\mathbf{P H}^{2}$ \\ ${ }^{1}$ RSJD Dr Amino Gondhohutomo Semarang \\ ${ }^{2}$ Program studi Ners, Sekolah Tinggi Ilmu Kesehatan Kendal \\ jarfafafin@gmail.com
}

\begin{abstract}
ABSTRAK
Hemodialisis (cuci darah) merupakan suatu tindakan terapi pengganti ginjal yang telah rusak. Pasien yang menjalani hemodialisis mengalami masalah psikologis salah satunya yaitu ansietas. Ansietas terjadi dikarenakan kurangnya pengetahuan. Penelitian bertujuan untuk mengetahui gambaran tingkat ansietas, pasien dan keluarga pasien hemodialisis di RS Kendal. Metode penelitian menggunakan survey deskriptif kuantitatif.Alat ukur menggunakan 14 pertanyaan terkait ansietas pada kuesioner DASS (Depression Anxiety Stress Scale).Sampel penelitian berjumlah 60 pasien dan 60 keluarga pasien.Hasil penelitian menunjukkan bahwa mayoritas pasien dan keluarga pasien mengalami ansietas pada tingkat berat. Hasil penelitian ini direkomendasikan kepada peneliti selanjutnya agar dapat memberikan intervensi yang efektif untuk mengatasi ansietas pasien dan keluarga pasien hemodialisis.
\end{abstract}

Kata kunci: Ansietas, Pasien dan Keluarga pasien hemodialisis

\section{DESCRIPTION OF PATIENT ANSIETAS LEVELS AND FAMILY OF HEMODIALYSIS PATIENTS}

\begin{abstract}
Hemodialysis (dialysis) is an action therapy for kidney replacement that has been damaged. Patients who undergo hemodialysis experience psychological problems, one of which is anxiety. Anxiety occurs due to lack of knowledge. The study aims to describe the level of anxiety, patients and families of hemodialysis patients in Kendal Hospital. The research method used a quantitative descriptive survey. Measuring instruments used 14 questions related to anxiety on the DASS questionnaire (Depression Anxiety Stress Scale). The research samples were 60 patients and 60 patient families. The results showed that the majority of patients and families of patients experienced anxiety at a severe level. The results of this study were recommended to future researchers in order to be able to provide effective interventions to overcome the anxiety of patients and families of hemodialysis patients.
\end{abstract}

Keywords: Anxiety, Patients and Families of hemodialysis patients

\section{PENDAHULUAN}

Gangguan jiwa adalah suatu sindrom atau pola psikologis atau perilaku yang penting secara klinis yang terjadi pada seseorang dan dikaitkan dengan adanya distress atau disabilitas disertai peningkatan resiko kematian yang menyakitkan, nyeri, disabilitas, atau kehilangan kebebasan (American Psychiatric Association 2000 dalam Varcarolis, 2006). Menurut (Townsend, 2005) mengungkapkan gangguan jiwa adalah respon maladaptive terhadap stressor dari lingkungan internal dan eksternal yang ditunjukkan dengan pikiran, perasaan, tingkah laku yang tidak sesuai dengan norma local dan budaya setempat, dan mengganggu fungsi sosial, pekerja, dan fisik individu. Salah satu gangguan jiwa yang menjadi penyebab penderita dibawa ke rumah sakit adalah perilaku kekerasan. Peilaku kekerasan (PK) adalah suatu bentuk perilaku agresi atau kekerasan yang ditunjukkan secara verbal, fisik, atau keduanyakepada suatu subyek, orang atau diri sendiri yang mengarah pada potensial untuk destruktif atau secara aktif menyebabkan kesakitan, bahaya, dan penderitaan (Bernstein \& Saladino, 2007).

Menurut rekam medic RSJD Dr. Amino Gondohutomo Semarang tahun 2015 , presentase penderita gangguan jiwa selama tahun 2014 yaitu klien rawat inap laki-laki sebanyak $65,3 \%$ dan 
$34,7 \%$ perempuan. Sedangkan pada bulan Januari sampai Juli 2016 sebanyak 2294 orang, diantaranya 1162 halusinasi $(50,65 \%)$, menarik diri 462 orang $(20,13 \%)$, harga diri rendah 374 orang $(5,66 \%)$, perilaku kekerasan 128 orang $(5,58 \%)$, defisit perawatan diri 21 orang $(0,91 \%)$, kerusakan komunikasi verbal 16 orang $(0,70 \%)$, percobaan bunuh diri 1 orang $(0,40 \%)$.

Pasien gangguan jiwa skizofrenia paranoid dan gangguan psikotik dengan gejala curiga berlebihan, galak, dan bersikap bermusuhan. Gejala ini merupakan tanda dari pasien yang mengalami perilaku kekerasan (Medikal Record, 2009). Masalah yang sering muncul pada klien gangguan jiwa khususnya dengan kasus perilaku kekerasan salah satunya adalah tindakan marah. Tindakan yang dilakukan perawat dalam mengurangi resiko perilaku kekerasan salah satunya adalah dengan menggunakan strategi pelaksanaan (SP). SP merupakan pendekatan yang bersifat membina hubungan saling percaya antara klien dengan perawat, dan dampak apabila tidak diberikan SP akan membahayakan diri sendiri maupun lingkungannya. Dari hasil observasi yang telah dilakukan oleh perawat, kami tertarik untuk melakukan studi kasus mengenai penerapan stategi pelaksanaan (SP) perilaku kekerasan yang paling efektif di ruang rawat inap laki laki RSJD Dr. Amino Gondohuttomo Semarang.

Strategi pelaksanaan (SP) yang dilakukan oleh klien dengan perilaku kekerasan adalah diskusi mengenai cara mengontrol perilaku kekerasan secara fisik, obat, verbal, dan spiritual. Mengontrol perilaku kekerasan secara fisik dapat dilakukan dengan cara nafas dalm, dan pukul bantal atau kasur. Mengontrol secara verbal yaitu dengan cara menolak dengan baik, meminta dengan baik, dan mengungkapkan dengan baik. Mengontrol perilaku kekerasan secara spiritual dengan cara shalat dan berdoa. Serta mengontrol perilaku kekerasan dengan minum obat secara teraturdengan prinsip lima benar (benar klien, benar nama obat, benar cara minum obat, benar waktu minum obat, dan benar dosis obat). Dari keempat SP yang digunakan untuk mengontrol perilaku kekerasan, peneliti ingin mengetahui SP nomor berapa yang paling efektif digunakan pada pasien perilaku kekerasan.

\section{METODE}

Penelitian ini menggunakan pendekatan kualititatif, penelitian yang menghasilkan data deskriptif berupa kata-kata tertulis maupun lisan dari orang-orang dan perilaku yang diamati (Meloang, 2007). Penelitian ini dilakukan untuk mengetahui SP perilaku kekerasan yang paling efektif menurut pendapat responden. Populasi dalam penelitian ini adalah semua pasien dengan masalah resiko perilaku kekerasan di ruang Rawat Inap Laki laki RSJD Dr. Amino Gondhutomo Semarang. Adapun kriteria inklusi dari penelitian ini antara lain pasein sehat secara fisik, pasien dengan resiko perilaku kekerasan, mampu berkomunikasi dengan baik, pasien kooperatif dan dapat mengungkapkan perasannya secara verbal dengan baik. Teknik pengambilan sampel dalam penelitian ini menggunakan teknik purposive sampling (judgment sampling). Peneliti mengkaji faktor predisposisi, kondisi fisik dan status mental klien dengan resiko perilaku kekerasan dan menetapkan sampel berdasarkan kriteria inklusi. Jumlah sampel yang digunakan pada penelitian ini sebanyak 6 penderita skizofrenia dengan resiko perilaku kekerasan di ruang rawat inap laki laki RSJD Dr. Amino Gondohutomo. Alat penelitian yang digunakan meliputi, lembar observasi, kertas dan recorder. Cara pengumpulan data pada penelitian dilakukan dengan melakukan kontrak waktu, melakukan indeept interview, menvalidasi dan menyimpulkan jawaban informan informan, mendokumentasikan respon informan, dan mengakhiri dengan penutupan serta salam.

\section{HASIL}

Hasil penelitian berupa transkip wawancara yang telah peneliti buat kemudian dikategorikan sesuai dengan kata kunci yang telah disajikan dalam tabel dan skema berikut : 
Tabel 1. Kategori dan kata kunci

\begin{tabular}{|c|c|}
\hline Kategori & Kata Kunci \\
\hline \multirow[t]{2}{*}{ Marah } & Marah secara verbal seperti berbicara kasar dan keras \\
\hline & Marah secara tindakan seperti mengamuk, memukul, merusak barang \\
\hline \multirow[t]{2}{*}{ Penyebab marah } & Diri sendiri : merasa curiga ada yang ingin jahat pada dirinya \\
\hline & $\begin{array}{l}\text { Orang lain : kata-kata yang menyinggung dan membuat marah, diacuhkan dan } \\
\text { diabaikan orang lain, dikhianati }\end{array}$ \\
\hline \multirow{2}{*}{$\begin{array}{l}\text { Yang dilakukan } \\
\text { ketika marah }\end{array}$} & Secara verbal : berbicara kasar dan ngomel-ngomel \\
\hline & Secara fisik :berkelahi, membanting barang, membakar barang \\
\hline Kategori & Kata Kunci \\
\hline \multirow[t]{2}{*}{ Marah berhenti jika } & Secara verbal : ketika dimarahin orang lain, ketika lelah sendiri \\
\hline & $\begin{array}{l}\text { Secara tindakan : ketika merasa uas dengan tindakan yang dilakukan seperti } \\
\text { membacok, menghancurkan barang }\end{array}$ \\
\hline \multirow[t]{2}{*}{ Mengontrol PK } & Sudah : sudah pernah diajarkan SP minimal SP 1 \\
\hline & Belum : belum diajarkan SP sama sekali \\
\hline \multirow[t]{5}{*}{ Efektivitas SP } & Nafas dalam \\
\hline & Pukul bantal \\
\hline & Verbal dengan menolak dan meminta sesuatu secara baik \\
\hline & Spiritual : berdoa, dzikir, calming teknique, \\
\hline & Obat \\
\hline \multirow[t]{2}{*}{ Perassaan } & Lega : tidak ada beban didalam hati \\
\hline & Tenang : hati adem \\
\hline \multirow[t]{2}{*}{ Pelaksanaan SP } & Mandiri : dilakukan secara mandiri \\
\hline & Diingatkan : harus ada orang yang mengingatkan saat pelaksanaan SP \\
\hline \multirow{4}{*}{ Kuantitas } & Selalu : >3x sehari \\
\hline & Jarang : 2x sehari \\
\hline & Kadang : $1 \mathrm{x}$ sehari \\
\hline & Tidak pernah : 0 \\
\hline
\end{tabular}


Tabel 2.

Tema, Sub tema dan Kategori

\begin{tabular}{|c|c|c|}
\hline Tema & Sub tema & Kategori \\
\hline \multirow{36}{*}{$\begin{array}{l}\text { Pengetahuan pasien } \\
\text { tentang perilaku } \\
\text { kekerasan }\end{array}$} & \multirow{4}{*}{ Penyebab masuk RSJ } & 1. $\quad$ Tindakan : mengamuk \\
\hline & & Verbal : marah-marah \\
\hline & & Tindakan : memukul \\
\hline & & 4. $\quad$ Tindakan : merusak barang \\
\hline & \multirow{4}{*}{ Penyebab mengamuk } & Orang lain : Tersinggung \\
\hline & & Orang lain : Tidak diperhatikan \\
\hline & & Diri sendiri : Curiga \\
\hline & & 4. $\quad$ Orang lain : Dikhianati \\
\hline & \multirow{4}{*}{ Yang dilakukan ketika marah } & 1. Fisik : Berkelahi \\
\hline & & $\begin{array}{ll}\text { 2. } & \text { Fisik : Membanting barang-barang }\end{array}$ \\
\hline & & 3. $\quad$ Verbal : Bicara kasar \\
\hline & & 4. $\quad$ Fisik : Membakar \\
\hline & \multirow[t]{4}{*}{ Marah berhenti, jika melakukan } & 1. Tindakan : membacok \\
\hline & & 2. Verbal : dimarahin \\
\hline & & 3. $\quad$ Verbal : ketika klien merasa lelah \\
\hline & & Tindakan : menghancurkan barang \\
\hline & \multirow{4}{*}{$\begin{array}{l}\text { Diajarkan cara mengontrol } \\
\text { Perilaku Kekerasan }\end{array}$} & 1. $\quad$ Sudah : SP1-SP 4 \\
\hline & & 2. $\quad$ Sudah : SP1-SP 4 \\
\hline & & 3. $\quad$ Sudah : SP1-SP 4 \\
\hline & & 4. $\quad$ Sudah : SP1-SP 4 \\
\hline & \multirow{4}{*}{$\begin{array}{l}\text { Paling } \\
\text { marah }\end{array}$} & 1. $\quad$ Spiritual : Berdoa dan ikhlas \\
\hline & & Napas dalam dan berdoa / shalat \\
\hline & & Nafas dalam \\
\hline & & 4. Nafas dalam dan Pukul bantal \\
\hline & \multirow{4}{*}{$\begin{array}{l}\text { Perasaan setelah melakukan } \\
\text { cara mengontrol marah }\end{array}$} & Lega \\
\hline & & 2. $\quad$ Tenang \\
\hline & & Tenang \\
\hline & & Lega \\
\hline & \multirow{4}{*}{$\begin{array}{l}\text { Melakukan SP secara mandiri } \\
\text { atau diingatkan }\end{array}$} & 1. $\quad$ Mandiri \\
\hline & & Mandiri \\
\hline & & 3. $\quad$ Mandiri \\
\hline & & Mandiri \\
\hline & \multirow[t]{4}{*}{ Kuantitas } & Kadang-kadang : 1x sehari \\
\hline & & 2. Kadang-kadang : 1x sehari \\
\hline & & 3. $\quad$ Kadang-kadang : 1x sehari \\
\hline & & 4. Kadang-kadang : 1x sehari \\
\hline $\begin{array}{l}\text { Masing-masing tema } \\
\text { penelitian akan dijelas } \\
\text { 1. Pengetahuan pasieı }\end{array}$ & $\begin{array}{l}\text { yang didapat dari hasil } \\
\text { an sebagai berikut: } \\
\text { tentang perilaku kekerasan }\end{array}$ & $\begin{array}{l}\text { Saya dibawa kesini karena suka } \\
\text { ngamuk mbak, suka marah juga samo } \\
\text { mukul orang” }\end{array}$ \\
\hline
\end{tabular}

Tema ini terdari dari sub tema antara lain :

a. Penyebab masuk RSJ
1) Marah : 5 dari 6 informan menyatakan dibawa ke RSJ karena marah- marah

"Marah-marah"

2) Mengamuk : 4 dari 6 informan menyatakan dibawa ke RSJ karena mengamuk.

"Mengamuk"

3) Memukul : 2 dari 6 informan menyatakan dibawa RSJ karena memukul orang
4) Merusak barang : 1 dari 6 informan dibawa ke RSJ karena merusak barang

"Saya dibawa kesini karena suka ngamukngamuk mbak, suka mukul kaca jendela juga. Ya kaca jendelanya sampai pecah gitu."

b. Penyebab prilaku kekerasan

1) Tersinggung : 5 dari 6 informan menyatakan mengamuk karena tersinggung

"Biasanya karena saya nggak tidur, terus pusing terus ada yang menyinggung atau 
membuat saya marah, itu saya langsung ngamuk"

2) Tidak diperhatikan : 4 dari 6 informan mengatakan mengamuk karena tidak diperhatikan keluarganya

"Soalnya saya kesel sama ibu saya, yang ga merhatiin saya"

3) Curiga : 2 dari 6 informan mengatakan mengamuk karena curiga terhadap orang yag berniat jahat padanya

"Saya merasa ada orang yang ingin jahat kepada saya, yang akan membunuh saya"

4)Dikhianati/ tidak dihargai : 4 dari 6 informan mengatakan mengamuk karena telah dikhianati "Saya ngamuk kayak gini gara-gara diselingkuhi istri mbak. Dia selingkuh coba dengan teman kerjanya"

c. Yang dilakukan ketika marah

1) Berkelahi : 2 dari 6 informan mengatakan ketika marah akan berperang (bertengkar).

"Perang, tawuran sama orang kecamatan lain, bacok-bacokan"

2) Membanting barang-barang : 3 dari 6 informan mengatkan ketika marah akan membanting barang-barang

"Kadang mbanting barang juga.", saya membakar sepeda"

3)Berbicara kasar : 5 dari 6 informan mengatakan ketika marah bicara kasar

"Ya saya biasanya ngomel gitu mbak,"

d.Diajarkan cara mengontrol marah

1) Sudah : Semua informan menyatakan sudah pernah diajari cara mengontrol marah

"Sholat dan berdoa, iklas menerima"

e.Paling efektif mengontrol marah

1) Berdoa dan iklas menerima kenyataan : 5 dari 6 informan mengatakan yang paling efektif mengontrol marah adalah dengan berdoa atau sholat dan menerima semuanya dengan iklas

"Sholat dan berdoa, iklas menerima"

2) Nafas dalam : 5 dari 6 informan mengatakan yang paling efektif mengontrol marah adalah dengan nafas dalam

"Kadang juga nafas dalam sambil istigfar"

3) Pukul bantal : 2 dari 6 informan mengatakan yang paling efektif mengontrol marah adalah dengan pukul bantal

"Saya sering melakukan pukul bantal mba. Saya latihan pukul bantal 10-15 menit." f. Perasaan setelah melakukan cara mengontrol marah

1)Lega : 5 dari 6 informan mengatakan merasa lega setelah melakukan cara mengontrol marah

"Ya perasaan saya sedikit lega, soalnya bisa marah tanpa melukai orang lain. saya kalau ngontrol PK itu sendiri mbak"

2)Tenang : 3 dari 6 informan mengatakan merasa tenang setelah melakukan cara mengontrol marah

"Ya perasaan saya lebih tenang mba setelah nafas dalam. Jadi lebih adem aja hatinya.

\section{PEMBAHASAN}

Hasil penelitian diatas didapatkan dari 6 informan menyatakan melakukan Prilaku kekerasan karena tersinggung 5, karena tidak dihargai / diperhatikan 4, dan hanya 2 informan curiga terhadap orang yag berniat jahat padanya. Faktor pencetus terjadinya perilaku kekerasan terbagi dua yaitu dari dalam diri klien sendiri dan dari lingkungan. Faktor di dalam diri seperti kelemahan fisik, keputusasaan, ketidakberdayaan, dan kurang percaya diri. Selain itu faktor lingkungan yang menjadi penyebab perilaku kekerasan seperti kehilangan orang atau objek yang berharga dan konflik interaksi sosial (Yosep, 2007).

Hasil penelitian diatas menunjukkan dari 6 informan menyatakan yang paling efektif mengontrol marah adalah : dengan berdoa dan ikhlas menerima kenyataan yang sudah terjadi 5. Hal ini sesuai dengan penelitian sebelumnya yang mengatakan bahwa mengontrol marah dapat dilakukan dengan menggunakan pendekatan spiritual melalui calming technique dan saling memaafkan pada pasien skizofrenia dengan resiko perilaku kekerasan (Padma,S \& Dwidiyanti, M, 2014).Selain itu penelitian psikiatrik membuktikan bahwa ada hubungan yang signifikan antara komitmen agama dan kesehatan, yaitu seseorang yang taat menjalankan ajaran agama relatif lebih sehat dan mampu mengatasi penyakitnya sehingga proses penyembuhan penyakit lebih cepat (Zainul, 2007). Menurut (Sulistyowati \& Prihantini, 2015) menunjukkan bahwa adanya pengaruh terapi psikoreligius terhadap penurunan perilaku kekerasan pada pasien skizofrenia di RSJD Surakarta.

Hasil penelitian juga menunjukkan 5 informan menyatakan yang paling efektif untuk mengontrol perilaku kekerasan adalah dengan nafas dalam. Hasil penelitian ini sejalan dengan penelitian yang dilakukan oleh Zelianti (2011) 
tentang pengaruh tehnik relaksasi nafas dalam terhadap tingkat emosi klien perilaku kekerasan di Rumah Sakit Jiwa Daerah Dr. Amino Gondohutomo yang menyatakan ada pengaruh yang signifikan antara tehnik relaksasi nafas dalam terhadap tingkat emosi klien perilaku kekerasan. Selain itu penelitian lain menyebutkan bahwa, ada pengaruh pemberian tehnik relaksasi nafas dalam terhadap kemampuan pasien mengendalikan perilaku kekerasan di Ruang Bratasena RSJ Provinsi Bali.

Melihat hasil diatas dengan dilakukannya pendekatan Spiritual dan Napas Dalama dapat memberikan efek menenangkan dan merelaksasi pikiran , sehingga klien dapat mengontrol emosiny, bahkan 5 informan menyatakan lega setelah melakukan cara mengontrol emosi yang dilakukannya sedangkan 3 lainnya menyatakan merasa lega dan tenang setelah mengontrol emosinya.

Cara mengontrol perilaku kekerasan yang menurut informan efektif adalah pukul bantal. Beberapa penelitian tentang aktivitas fisik dan terapi olahraga terhadap gangguan kejiwaan membuktikan, bahwa aktivitas fisik tersebut dapat meningkatkan kepercayaan pasien terhadap orang lain (Campbell \& Foxcroft, 2008), dan juga membantu mengontrol kemarahan pasien (Hassmen, Koivula \& Uutela, 2000). Oleh karena itu klien perlu dilatih mengontrol amarahnya dengan melakukan kegiatan fisik sehingga dapat berperilaku lebih adaptif dalam situasi-situasi dalam hidupnya berikutnya.

\section{SIMPULAN DAN SARAN \\ Simpulan}

1. Penerapan stategi pelaksanaan (SP) perilaku kekerasan yang paling efektif menurut pasien perilaku kekerasan di ruang rawat inap laki laki RSJD Dr. Amino Gondohuttomo Semarangadalah dengan cara Spiritual dan Napas Dalam.

2. Penerapan strategi pelaksanaan (SP) spiritual yang paling efektif tersebut menurut menurut pasien perilaku kekerasan di ruang rawat inap laki laki RSJD Dr. Amino Gondohuttomo Semarang karena memberikan ketenangan dan rasa lega.

\section{Saran}

Perawat dapat lebih melatih kemampuan pasien perilaku kekerasan mengotrol perilaku kekerasan dengan mengajari Relaksasi Napas Dalam dan cara spiritual seperti sholat, mengaji dan berdzikir.

\section{DAFTAR PUSTAKA}

Bernstein, K.S \& Saladino, J.P. 2007. Clinical assessment and management of psychiatric patient's violent and aggressive behaviors in general hospital. Medsurg, 16 (5), 301-9, 331. PMID: 18072668.

Carpenito, Lynda Juall. 2000. Buku Diagnosa Keperawatan. Editor Monica Ester. EGC : Jakarta.

Dossey, M. 2008. Holistic nursing: a handbook for practice. Janes \& Bartlitt publisher, Canada: Missisauga.

Keliat, B.A. 1998. Proses Keperawatan Jiwa. Jakarta: EGC

Moleong, Lexy J. 2007. Metodologi Penelitian Kualitatif, Penerbit PT Remaja Rosdakarya Offset, Bandung

Padma,Sri \& Dwidiyanti, Meidiana. 2014. Studi kasus: mindfulness dengan pendekatan spiritual pada pasien skizofrenia dengan resiko perilaku kekerasan. Program studi ilmu keperawatan, fakultas kedokteran Universitas Diponegoro. Konas Jiwa XI Riau: Hal 290-294.

Pramudaningsih I, Soekarno C, Susilowati Y. Pemberian Strategi pelaksanaan pada klien gangguan jiwa dengan perilaku kekerasan di ruang citro anggodo RSJD Dr. Amino Gondohutomo Semarang. 2014. Jurnal profesi keperawatan: vol 1 no.1, hal 1-116, ISSN 2355-8040

Sulistyowati, D \& Prihantini. 2015. Pengaruh terapi psikoreligi terhadap penurunan perilaku kekerasan pada pasien skizofrenia di Rumah Sakit Jiwa Daerah Surakarta. Jurnal terpadu ilmu kesehatan, Vol 4, No. 1, Hal: 72-77. Kementrian kesehatan politeknik kesehatan Surakarta jurusan keperawatan.

Sumirta, Nengah I, Githa, Wayan I \& Sariasih, Nengah Ni. 2013. Relaksasi Nafas Dalam Terhadap Marah Klien Dengan Perilaku Kekerasan. Denpasar

Townsend, C.M. 2005. Essentials of psychiatric mental health nursing. Philadelphia: F.A Davis Company. 
Varcarolis, E.M. 2006. Psychiatric nursing clinical assament tools and diagnosis. Philadelphia: W.B Sounders Co.
Zelianti. 2011. Pengaruh Tehnik Relaksasi Nafas Dalam Terhadap Tingkat Emosi Klien Perilaku Kekerasan di RSJD Dr Amino Gondohutomo Semrang. 